\title{
Water relations of chives in function of salinity and circulation frequency of nutrient solutions
}

Fernando J. da Silva Júnior ${ }^{1}$, José A. Santos Júnior ${ }^{1}$, Manassés M. da Silva ${ }^{1}$, Ênio F. de F. e Silva ${ }^{1}$ \& Edivan R. de Souza ${ }^{1}$

${ }^{1}$ Universidade Federal Rural de Pernambuco/Programa de Pós-Graduação em Engenharia Agrícola, Recife, PE, Brasil. E-mail: nando_fj18@hotmail.com ORCID: 0000-0003-2181-7303; joseamilton@ufrpe.br (Corresponding author) - ORCID: 0000-0002-1656-7103; manasses.mesquita@ufrpe.br - ORCID: 0000-0002-3316-8024; enio.fsilva@ufrpe.br - ORCID: 0000-0002-8652-503X; edivan.rodrigues@ufrpe.br - ORCID: 0000-0002-2442-7266

ABSTRACT: Hydroponic cultivation using saline waters is an alternative for agricultural production, especially in the cultivation of vegetables. Therefore, the present work was conducted with the objective of evaluating the water consumption, water use efficiency and water content, as well as dry matter partitioning of chives (Allium schoenoprasum), cv. Todo Ano Evergreen - Nebuka exposed to six levels of nutrient solution salinity $\left(1.5,3.0,4.5,6.0,7.5\right.$ and $\left.9.0 \mathrm{dS} \mathrm{m} \mathrm{m}^{-1}\right)$, applied at two circulation frequencies (twice a day at 8 and $16 \mathrm{~h}$; and three times a day - at 8,12 and $16 \mathrm{~h}$ ). The level in the nutrient solution reservoir, which decreased according to the water consumption by plants, was replaced with the respective saline water (Experiment I) and supply water (Experiment II). Both experiments used a completely randomized design, in a $6 \times 2$ factorial scheme, with five replicates. It was observed that increased circulation frequency and the use of supply water in the replacement mitigated the effects of salinity on water consumption, water use efficiency and water content in the plant. However, with the increase in nutrient solution electrical conductivity, dry matter allocation in the roots increased, to the detriment of the shoots.

Key words: Allium schoenoprasum, cultivation of vegetables, soilless cultivation

\section{Relações hídricas da cebolinha em função da salinidade e frequência de circulação de soluções nutritivas}

RESUMO: O cultivo hidropônico com o uso de águas salobras, constitui-se em uma alternativa para a produção agrícola, especialmente no cultivo de hortaliças. Sendo assim, desenvolveu-se o presente trabalho com o objetivo de avaliar o consumo, eficiência e o teor de água, bem como a partição de massa seca de plantas de cebolinha (Allium schoenoprasum), cultivar Todo Ano Evergreen - Nebuka, expostas a seis níveis de salinidade da solução nutritiva $\left(1,5 ; 3,0 ; 4,5 ; 6,0 ; 7,5\right.$ e 9,0 dS m$~^{-1}$ ), aplicados em duas frequências de circulação (duas vezes ao dia - às 8 e $16 \mathrm{~h}$; e três vezes ao dia - às 8,12 e $16 \mathrm{~h}$ ). O nível do reservatório de solução nutritiva, que reduzia em função do consumo hídrico das plantas, foi reposto com a respectiva água salobra (Experimento I) e de água de abastecimento (Experimento II). Nos dois ensaios, adotou-se delineamento experimental inteiramente casualizado, analisado em esquema fatorial $6 \times 2$, com cinco repetições. Verificou-se que o aumento da frequência de circulação e o uso de água de abastecimento na reposição, mitigaram os efeitos da salinidade sobre o consumo e eficiência do uso e o teor de água na planta. Entretanto, com o incremento da condutividade elétrica da solução nutritiva, a alocação de matéria seca na raiz aumentou, em detrimento da parte aérea.

Palavras-chave: Allium schoenoprasum, cultivo de hortaliças, cultivo sem solo 


\section{INTRODUCTION}

Salinity is one of the stresses that most hamper crop yield. The first onus is the reduction in the osmotic potential of the cultivation medium, which may reduce water consumption, leading to water stress, a situation that triggers mechanisms of adjustment to the stress condition and directly influences the water content in the plant (Paulus et al., 2012) and dry matter allocation (Hasanuzzaman et al., 2014). These effects can also be noted in the reduction of growth, disorders in membrane permeability, activities of ionic exchange, photosynthesis and in ionic balance (Navarro et al., 2003).

In situations in which agricultural use of saline waters is indispensable, using compatible technology is essential. Among these techniques, soilless cultivation can be mentioned because, given the energetic order resulting from the minimization of matric potential, it leads to more expressive results than cultivation in soil under the same level of salinity (Santos Júnior et al., 2016).

However, even under hydroponic conditions, strategies of management of saline nutrient solutions, such as increased circulation frequency (Silva et al., 2016) and use of fresh water to replace the evapotranspired solution, are recommended (Lira et al., 2015; Soares et al., 2016), especially in the cultivation of vegetables such as chives.

Although Silva et al. (2014), discussing the initial growth of chives irrigated with saline water in soil, observed a reduction from $0.7 \mathrm{dS} \mathrm{m}^{-1}$; these authors also reported how scarce studies evaluating the response of chives to salinity are and also the management strategies for its mitigation (Soares et al., 2015).

Thus, the present study was conducted to evaluate water consumption, water use efficiency and water content in the plant, shoots and roots, as well as dry matter partitioning in chive plants exposed to strategies of replacement and frequency of application of nutrient solutions prepared in saline waters.

\section{Material and Methods}

Experimental activities were carried out from December 2016 to May 2017 in a greenhouse located at the Federal Rural University of Pernambuco, Recife-PE, Brazil ( $8^{\circ} 1^{\prime} 7^{\prime \prime} \mathrm{S}, 34^{\circ} 56^{\prime}$ $53^{\prime}$ W, at mean altitude of $6.5 \mathrm{~m}$ ). During the experimental period, maximum and minimum mean temperatures were 37.4 and $32.2^{\circ} \mathrm{C}$, respectively, with maximum and minimum relative humidity values of 61.4 and $44.5 \%$ inside the greenhouse.

Two experiments were conducted, both adopting a completely randomized design, analysed in $6 \times 2$ factorial arrangement with five replicates, considering five evaluated plants per experimental unit. Both experiments tested six levels of electrical conductivity of the nutrient solution - ECns (1.5, 3.0, 4.5, 6.0, 7.5 and $9.0 \mathrm{dS} \mathrm{m}^{-1}$ ) applied at two frequencies: the first one twice a day at 8 and $16 \mathrm{~h}$, and the second one three times a day - at 8,12 and $16 \mathrm{~h}$.

In the first experiment, the level of nutrient solution in the reservoir, which decreased according to the water consumption by plants, was replenished with the respective saline water used to prepare the nutrient solution, and in the second experiment, with water from the local supply system.
The hydroponic system consisted of PVC pipes (100 mm) adapted with circular perforations (60 $\mathrm{mm}$ diameter) every $0.14 \mathrm{~m}$, along $6.0 \mathrm{~m}$ in length. Elbows with the same diameter were attached on both ends and one of them was connected to a valve in order to maintain a 0.04 -m-deep film of solution along the level pipe. Twelve pipes were arranged on a $1.40 \mathrm{~m}$ wide, $6 \mathrm{~m}$ long, $1.8 \mathrm{~m}$ high triangle-shaped wooden support (Santos Júnior et al., 2016).

Nutrient solution of each treatment was prepared in $100 \mathrm{~L}$ reservoirs. Initially $90 \mathrm{~L}$ of water from the local supply system $\left(\mathrm{EC} \approx 0 \mathrm{dS} \mathrm{m}^{-1}\right)$ were added. Then, the empirical relationship of Richards (1954) was used to calculate, and then solubilize, the respective quantity of $\mathrm{NaCl}$, obtaining the saline waters $(\approx$ $0,1.5,3.0,4.5,6.0$ and $\left.7.5 \mathrm{dS} \mathrm{m}^{-1}\right)$, according to the treatments.

After that, an equal quantity of fertilizers (Table 1) was solubilized for all treatments, as recommended by Furlani (1999), thus obtaining the levels of electrical conductivity of the nutrient solution (ECns) according to treatments - 1.5, 3.0, $4.5,6.0,7.5$ and $9.0 \mathrm{dS} \mathrm{m}^{-1}$. It should be emphasized that such quantity of fertilizers was added to the reservoirs only once, at the beginning of the experiments.

Recycling of nutrients was adopted in the nutrient solution management, i.e., in each application $40 \mathrm{~L}$ of nutrient solution were manually added to the pipes, according to the treatments, and the surplus, based on the level of the valve inside the pipe, returned to the reservoirs.

The reduction in the levels of the reservoirs, due to water consumption by plants, was measured and the volume was replaced every 7 days, but the monitoring of ECns and $\mathrm{pH}$ of the nutrient solution ( $\mathrm{pHns}$ ) was carried out every day.

The chives cv. Todo Ano Evergreen - Nebuka was evaluated. Sowing was performed in $180 \mathrm{~mL}$ disposable plastic cups, perforated on sides and bottom, and filled with coconut fiber as the substrate. After sowing, the cups were placed in the pipes and received the nutrient solution recommended by Furlani (1999) for 24 days. At 25 days after sowing (DAS), the germinated plants received the previously established saline treatments.

At the end of the crop cycle (65 DAS), the variables analysed in each experiment were: (i) water consumption (WCns), based on the sum of the replaced volumes; (ii) water use efficiency in the production of shoot phytomass (fresh and dry, WUESFP and WUE-SDP, respectively), based on the relationship between the phytomass (fresh and dry) produced in the shoots and water consumption by plant; (iii) water content in the plant (WCP), shoots (WCS) and roots (WCR) per plant; (iv)

Table 1. Composition of the standard nutrient solution used (Furlani, 1999)

\begin{tabular}{|lr|}
\hline \multicolumn{1}{c}{ Salt or fertilizer } & g $1000 \mathrm{~L}^{-1}$ \\
\hline Special Hydro calcium nitrate $\left(\mathrm{Ca}\left(\mathrm{NO}_{3}\right)_{2}\right.$ & 750.00 \\
Potassium nitrate $\left(\mathrm{KNO}_{3}\right)$ & 500.00 \\
Monoammonium phosphate (MAP) & 150.00 \\
Magnesium sulfate $\left(\mathrm{MgSO}_{4}\right)$ & 400.00 \\
Copper sulfate $\left(\mathrm{CuSO}_{4}\right)$ & 0.15 \\
Zinc sulfate $\left(\mathrm{ZnSO}_{4}\right)$ & 50.00 \\
Manganese sulfate $\left(\mathrm{M}_{\mathrm{n}} \mathrm{SO}_{4}\right)$ & 1.50 \\
Boric acid $\left(\mathrm{H}_{3} \mathrm{BO}_{3}\right)$ & 1.50 \\
Sodium molybdate $\left(\mathrm{Na}_{2} \mathrm{MoO}_{4} 2 \mathrm{H}_{2} \mathrm{O}\right)$ & 0.15 \\
Ammonium molybdate $\left(\left(\mathrm{NH}_{4}\right)_{6} \mathrm{Mo}_{7} \mathrm{O}_{24}\right)$ & 0.15 \\
\hline Tenso-Fe $(\mathrm{FeEDDHMA}-6 \% \mathrm{Fe})$, & 30.00 \\
\hline
\end{tabular}


root/shoot ratio (R/S); and (v) dry matter partition of shoots (DMPS) and roots (DMPR), according to Magalhães (1985).

The results of the experiments were subjected separately to analysis of variance by $\mathrm{F}$ test. ECns levels were compared by regression analysis while circulation frequencies were compared by test of means (Tukey), using the Sisvar statistical program (Ferreira, 2011) at 0.05 probability level.

\section{Results AND Discussion}

In relation to ECns, under replacement with saline water (SAW), the solution with initial ECns of $1.5 \mathrm{dS} \mathrm{m}^{-1}$ did not exceed the recommended variation of $25 \%$ (Furlani, 1999) at any moment of the cycle. However, solutions with initial ECns of 3.0, 4.5, 6.0, 7.5 and $9.0 \mathrm{dS} \mathrm{m}^{-1}$ increased by more than $25 \%$ at 7, 14, 21, 28 and 35 DAS, respectively. Under replacement with supply water (SW), the reductions were less than $25 \%$ compared to the initial ECns levels.

For pHns, the recommendation is that it should be within the 5.5-6.5 range (Furlani, 1999). However, at ECns of $1.5 \mathrm{dS} \mathrm{m}^{-1}$, under replacement with SAW and SW, after 14 DAS, the $\mathrm{pH}$ was lower than 5.5, reaching 5.2 at the end of the cycle. In the other cases, $\mathrm{pHns}$ values were within the recommended range.

After empirical analysis, a lower mean value of water consumption was observed under replacement with SAW compared to SW. With ECns of $6.0 \mathrm{dS} \mathrm{m} \mathrm{m}^{-1}$ and circulation frequency of two and three times a day, for instance, under replacement with SAW, the mean consumption was 0.33 and $0.44 \mathrm{~L} \mathrm{plant}^{-1}$ for the production of plants with 11.50 and $11.72 \mathrm{~g}$,

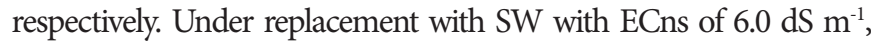
the consumption was equal to 0.46 and $0.73 \mathrm{~L} \mathrm{plant}^{-1}$ for the production of plants with 14.03 and $14.68 \mathrm{~g}$, respectively (Figures $1 \mathrm{~A}$ and $\mathrm{B}$ ).

Reduction in water consumption for nutrient solutions prepared in saline waters has already been observed for

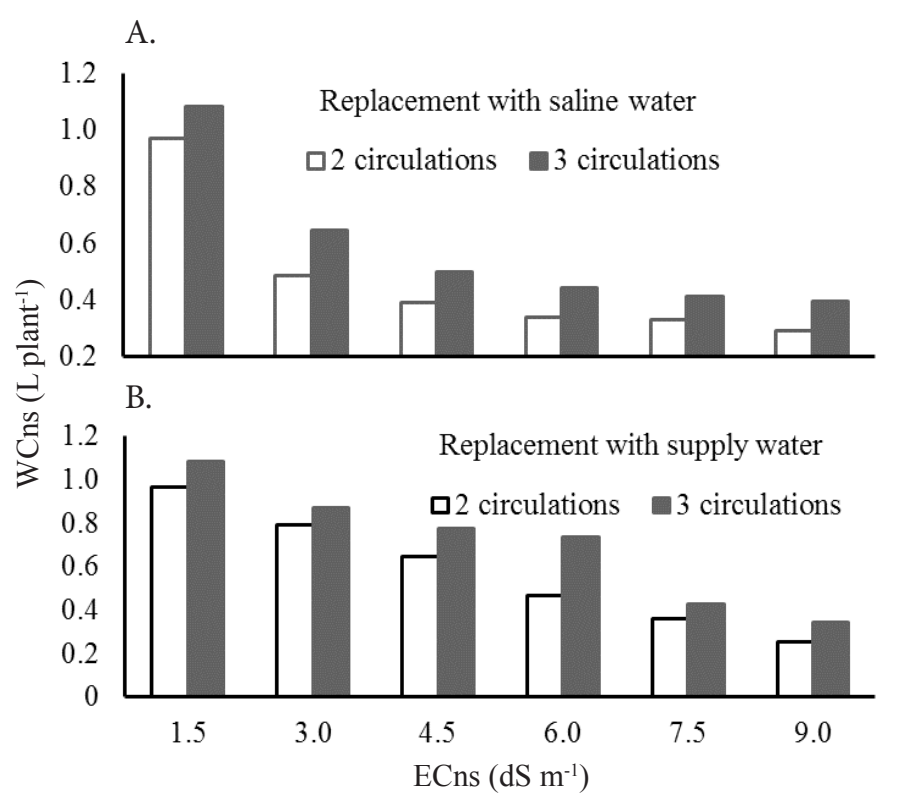

Figure 1. Means of water consumption (WCns) of chives (cv. Todo Ano Evergreen - Nebuka) under replacements and frequencies of application of nutrient solutions replacement with (A) saline water and (B) supply water lettuce (Paulus et al., 2012), coriander (Santos Júnior et al., 2015) and other vegetables (Silva et al., 2012). In all of these cases, the increase in ECns was associated with the reduction in the osmotic potential. Despite that, the use of increased frequency of circulation as a strategy to mitigate the effect of salts on water consumption may be associated with the lower variation in the concentration of salts, greater homogenization and oxygenation of the nutrient solution (Soares et al., 2016).

The ECns caused changes $(\mathrm{p}<0.05)$ in all variables related to the water relations (Figure 2), whereas the circulation frequency influenced $(\mathrm{p}<0.05)$ the WUE and, under replacement with SAW, the WCP, WCS and WCR. For the interaction between treatments, under replacement with SAW, there was significant effect on WUE-SFP, WUE-SDP, WCP and WCS; and under replacement with SW, on WUE-SFP.

Under replacement with SAW, WUE-SFP (Figure 2A) decreased linearly by 0.5406 and $0.7358 \mathrm{~g} \mathrm{~L}^{-1}$ for every unit increase of ECns in $\mathrm{dS} \mathrm{m}^{-1}$, under two and three circulation frequency a day, respectively, within the salinity range studied. With the use of SW (Figure 2B), the losses per unit increase were lower ( 0.183 and $0.236 \mathrm{~g} \mathrm{~L}^{-1}$ under two and three circulation frequency a day, respectively).

Therefore, it can be inferred that the reduction in water consumption resulting from the increment in ECns probably triggered processes of adjustment to the osmotic stress which also limited phytomass production and water content maintenance (Aragão et al., 2009); these parameters were immediately influenced by the type of replacement and frequency of circulation of the nutrient solution.

In relation to WUE-SDP, the losses per unit increase in ECns, under replacement with SAW (Figure 2C), were estimated at 0.0465 and $0.0364 \mathrm{~g} \mathrm{~L}^{-1}$ (two and three circulation frequency a day, respectively) and under replacement with SW (Figure 2D), a relative reduction was estimated at $0.0229 \mathrm{~g} \mathrm{~L}^{-1}$, with average efficiency of 0.41 and $0.60 \mathrm{~g} \mathrm{~L}^{-1}$ under two and three circulation frequency a day, respectively.

The water limitation imposed by osmotic reduction and the consequent closure of stomata probably hampered $\mathrm{CO}_{2}$ assimilation (Tabagiba et al., 2014) and, consequently, dry matter production (Mantovani et al., 2013). Nevertheless, it should be pointed out that, especially under replacement with SAW, the increase of circulation frequency mitigated the effect of salts on the ratio of dry phytomass production per unit of water consumed by up to $43.53 \%\left(9.0 \mathrm{dS} \mathrm{m}^{-1}\right)$ (Figure 2C).

In the case of vegetables, the WCP indicated as ideal is within the range from 75 to $95 \%$ (Luengo \& Calbo, 2009). In the present study, in all treatments, the WCP was higher than $89 \%$. Under replacement with SAW, the variations of WCP (Figure 2E) in plants subjected to 1.5 and $9.0 \mathrm{dS} \mathrm{m}^{-1}$ were 3.87 and $4.15 \%$, under two and three circulation frequency a day, respectively.

When SW was used in the replacement, there was no interference of circulation frequency $(p>0.05)$; however, the WCP (Figure 2 F) decreased by $0.3465 \%$ for every unit increase in ECns. Such variation in WCP between plants under 1.5 and $9.0 \mathrm{dS} \mathrm{m}^{-1}$ may be associated with the partial stomatal closure, a strategy that favors the maintenance of plant water status and minimizes the reduction in WCP (Taiz \& Zeiger, 2009). 
A.

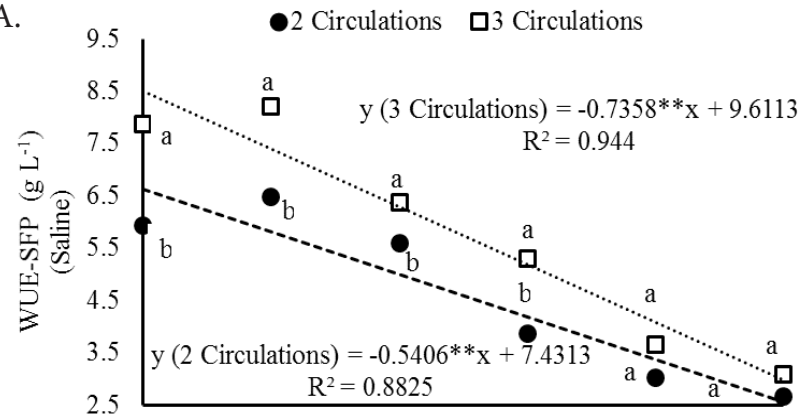

C.

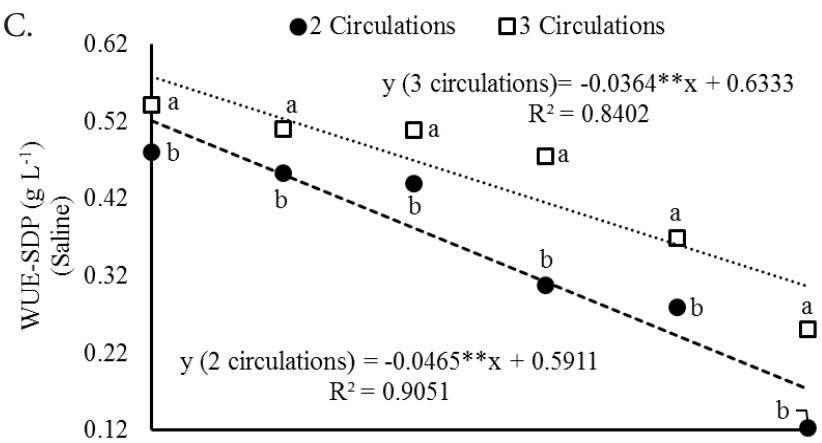

E.

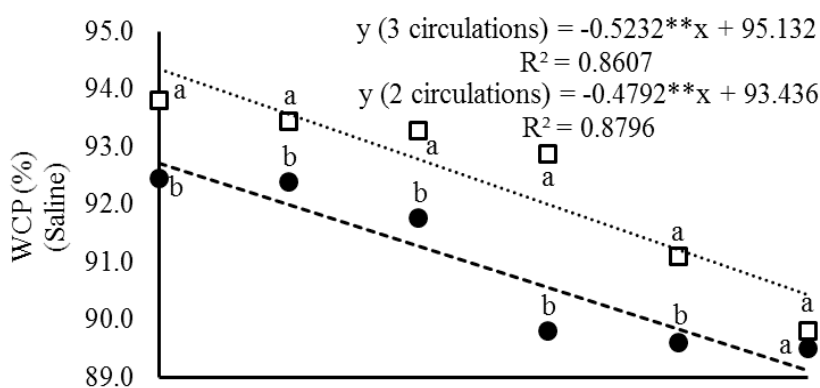

G.

- 2 Circulations $\square 3$ Circulations

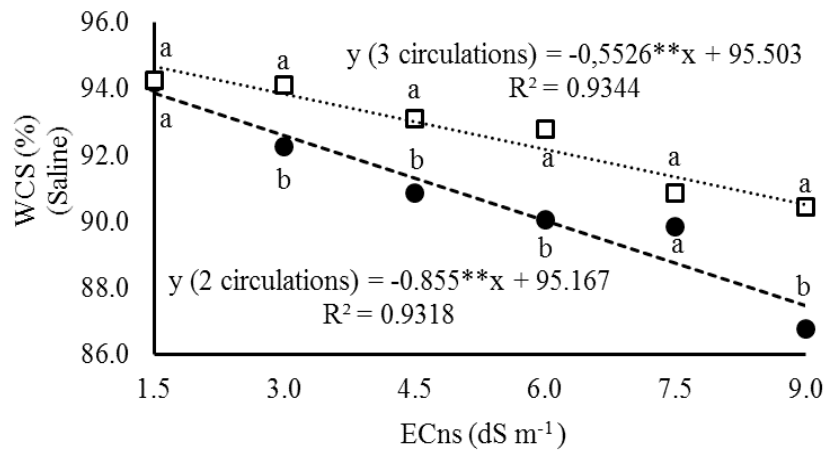

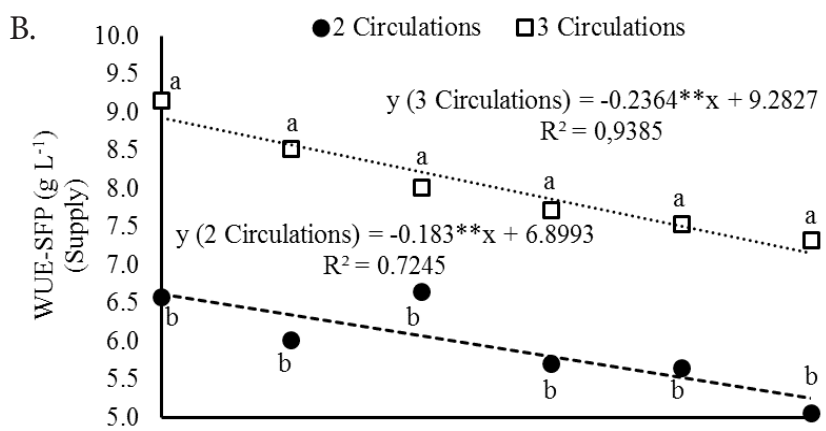

D.
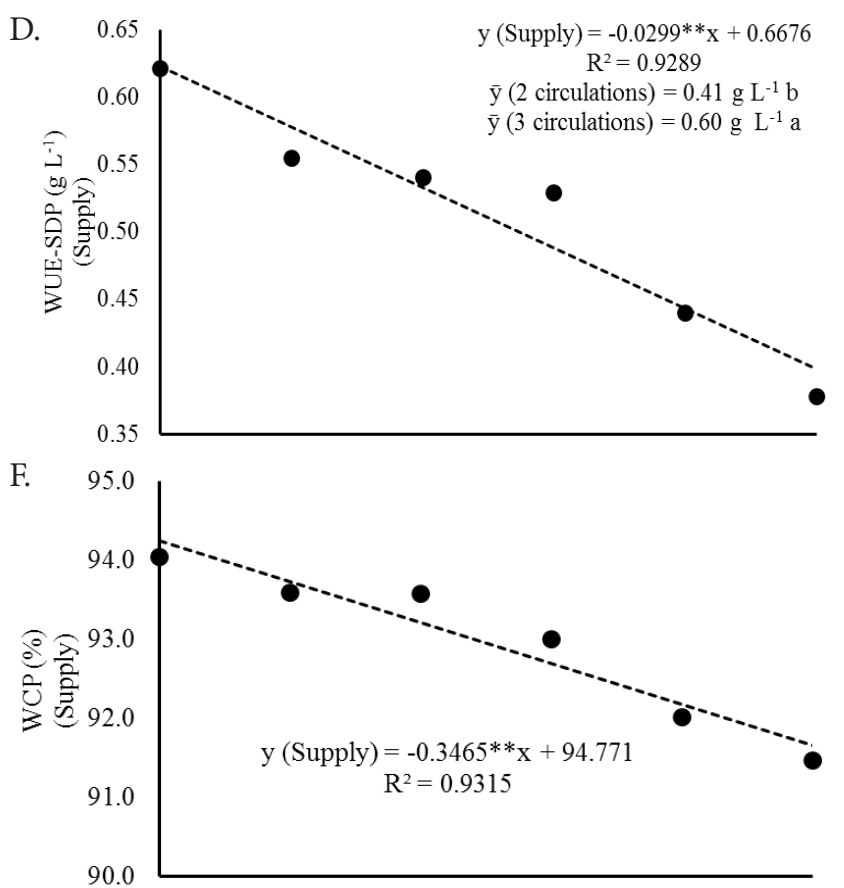

H. $\quad 94.5$

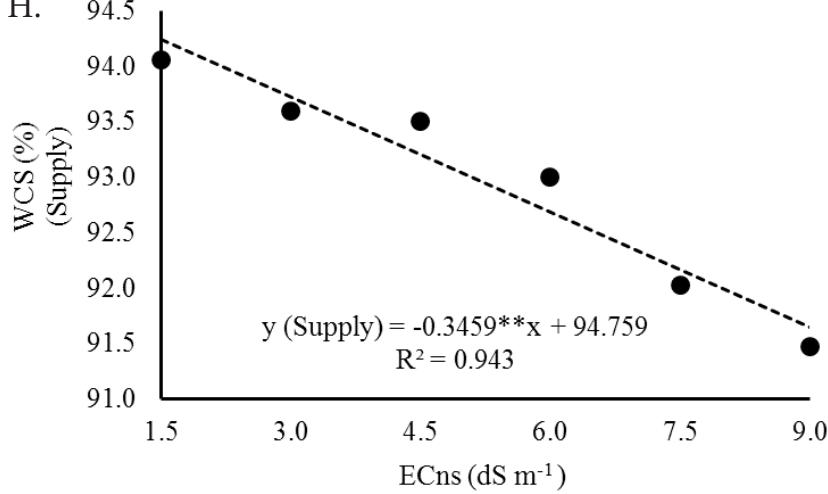

$\square$ Supply

$\mathrm{y}($ Supply) $=-0.631 * * \mathrm{x}+96.75$ $\mathrm{R}^{2}=0.9328$

$\square$

口

急

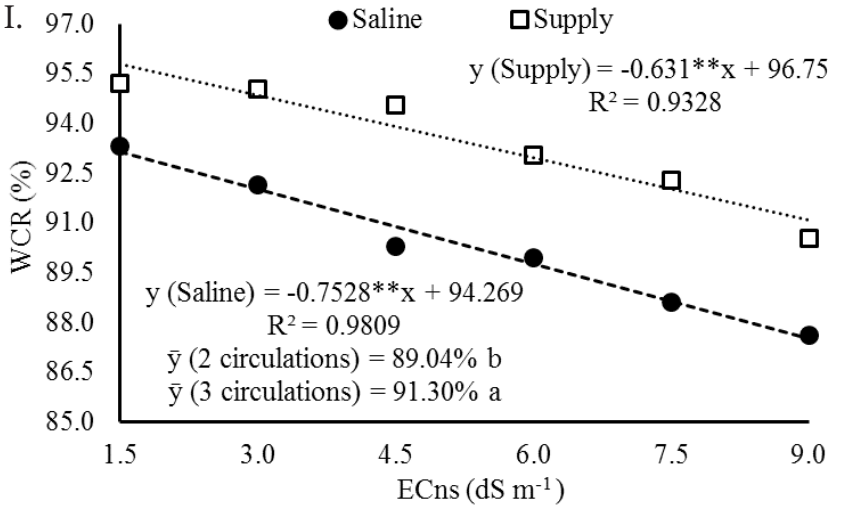

"."Significant at 0.01 and 0.05 probability levels, respectively by F test

Dots followed by the same letter at each level of salinity do no differ at 0.05 probability level by Tukey test

Figure 2. Water use efficiency (WUE) in the production of fresh (A and B) and dry (C and D) phytomass. Water content in the plant (WCP) (E and F), shoots (WCS) (G and H) and roots (WCR) (I) of chives cv. Todo Ano Evergreen - Nebuka under replacements of saline and supply waters and frequencies of circulation of nutrient solutions 
When WCS values were compared between plants under 1.5 and $9.0 \mathrm{dS} \mathrm{m}^{-1}$, there were reductions of 6.83 and $4.37 \%$ under two and three circulation frequency a day, respectively, under replacement with SAW (Figure $2 \mathrm{G}$ ) and, in relative terms, $0.365 \%$ under replacement with SW (Figure $2 \mathrm{H}$ ).

It is worth pointing out that the WCS was not below $85 \%$ in any of the treatments tested. However, its significant reduction, although numerically lower than those of other variables, has major impact on leaf texture, making them thicker. Similar results have also been reported with other vegetables, such as basil (Bione et al., 2014) and coriander (Santos Júnior et al., 2015).

In the roots, when SAW was used in the replacement, the WCR in plants under two circulation frequency a day (89.04\%) was lower than in that under three circulation frequency a day (91.3\%) (Figure 2I). The relative loss per unit increase in ECns, under replacement with SW, was $0.631 \%$.

Therefore, it can be inferred that, in the roots, the consequences of stress are immediate and result from the alterations in cell water relations, and they depend on stress intensity, as became evident in the difference between the results according to the water used in the replacement. However, the recovery process can also be more efficient because salts tend to be exported to the leaves, maintaining the levels of $\mathrm{Na}^{+}$and $\mathrm{Cl}^{-}$with constant trend over time (Willadino \& Camara, 2010).

In an overall analysis, given the difference observed in WCP, WCS and WCR according to the replacement water, it can be inferred that under replacement with SW probably there was higher efficiency in the osmotic adjustment performed by chive plants, evidencing also the circulation frequency $(p>0.05)$ as a mitigating agent.

The variables R/S, DMPS and DMPR were influenced $(\mathrm{p}<0.01)$ by ECns when the evapotranspired volume was replaced with SAW and SW (Figure 3 ). In addition, circulation frequency had significant $(\mathrm{p}<0.01)$ effect on $\mathrm{R} / \mathrm{S}$ in plants under replacement with SAW and on R/S and DMPR in plants under replacement with SW. The interaction between treatments caused significant effect on R/S ( $p<0.05)$ and no significant effect $(\mathrm{p}<0.05)$ on the other variables.

In plants under replacement with SAW (Figure 3A), the $\mathrm{R} / \mathrm{S}$ increased by $63.38 \%$ for two circulation frequency a day and by $48,5 \%$ for three circulation frequency a day, within the salinity range from 1.5 to $9.0 \mathrm{dS} \mathrm{m}^{-1}$. When SW was used (Figure 3B), the increments were $27.39 \%$ for two circulations day $^{-1}$ and $27.77 \%$ for three circulation frequency a day, within the studied range of salinity.

Although a mitigating effect of the increase in circulation frequency was observed, the increase of ECns imposed by the replacement with SAW probably resulted in higher losses in SDP, increasing the values of R/S.

In addition, there was lower influence of salinity due to the dilution of ECns by the replacement with SW. However, in both situations, the ECns clearly led to expressive alteration in the dry matter partitioning, as also observed for other vegetables (Paulus et al., 2010; Silva et al., 2013; Bione et al., 2014).

The reduction in DMPS occurred at rates of 2.18 and $2.71 \%$ for every unit increase of ECns in $\mathrm{dS}^{-1}$, under replacement
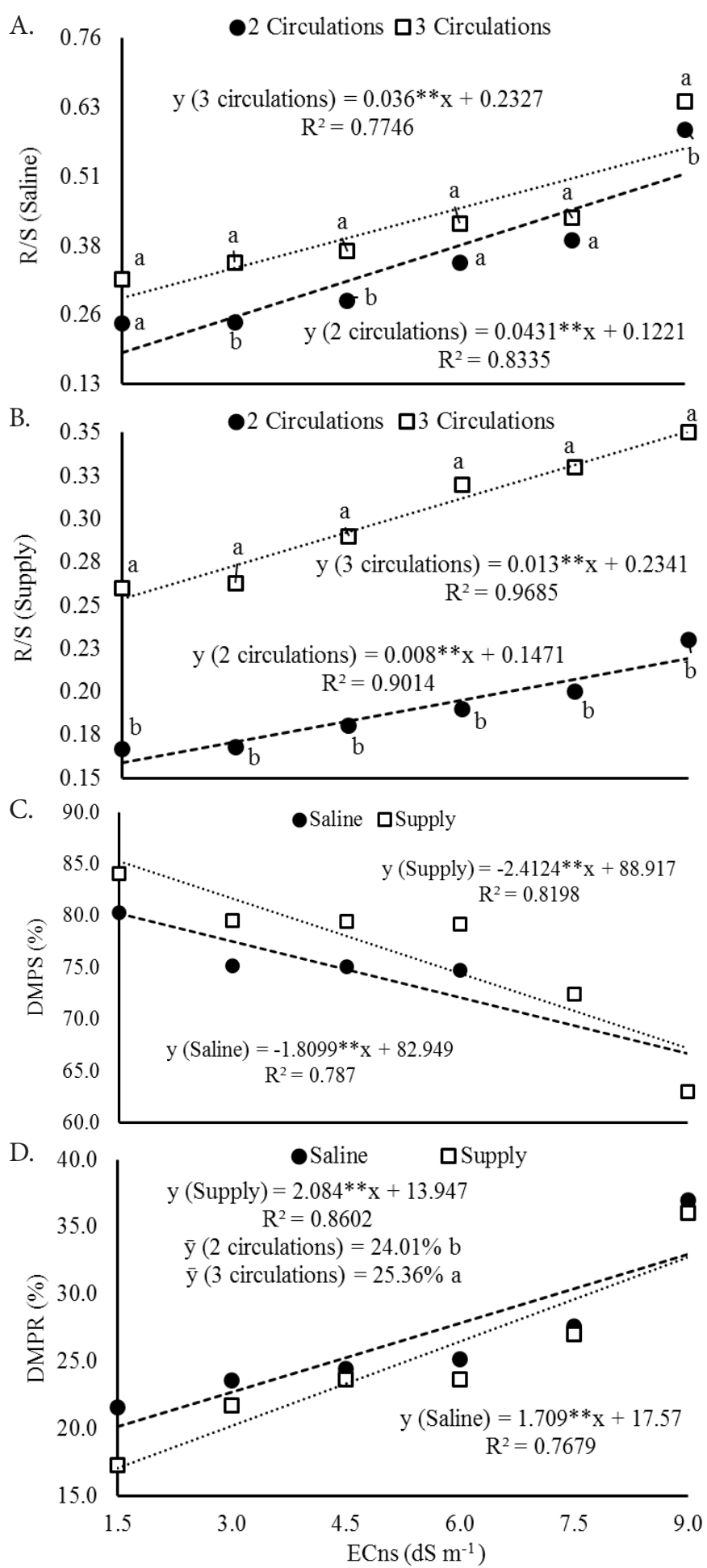

"; Significant at 0.01 and 0.05 probability levels, respectively by $\mathrm{F}$ test

Lines followed by the same letter at each level of salinity do not differ at 0.05 probability level by Tukey test

Figure 3. Root/shoot ratio (R/S) (A and B). Dry matter partition of shoots (DMPS) (C) and roots (DMPR) (D) of chives cv. Todo Ano Evergreen - Nebuka under replacements with saline and supply waters and frequencies of circulation of nutrient solutions

with SAW and SW, respectively (Figure 3C). In studies with other vegetables under salt stress, this trend has also been reported (Silva et al., 2013; Bione et al., 2014) and it expresses, in general terms, the deleterious result of the exportation and accumulation of salts in the shoots as a form of adjustment to the osmotic stress imposed (Silva et al., 2003). 
In the present study, as the ECns increased, the difference between DMPS in plants under replacement with SAW and SW decreased, being $4.16 \%$ under $3.0 \mathrm{dS} \mathrm{m}^{-1}$ and reaching $0.55 \%$ under $9.0 \mathrm{dS} \mathrm{m}^{-1}$.

Based on the trend of increase in dry matter accumulation in the roots under the imposed conditions of salinity (Figure $3 \mathrm{D})$, it can be inferred that salinity led to increase in dry matter allocation in the roots, to the detriment of the shoots, as also observed by other authors (Maciel et al., 2012; Bione et al., 2014), who attributed this result mainly to the reduction in shoot dry matter.

\section{Conclusions}

1. Although there were losses caused by salt stress, the water content in chives was higher than $85 \%$ in all plant parts.

2. Increased circulation frequency and use of supply water in the replacement mitigated the impacts caused by salt stress.

3. With increment in the electrical conductivity of the nutrient solution, the dry matter allocation in the roots increased, in detriment of the shoots.

\section{ACKNowledgments}

The authors thank the Conselho Nacional de Desenvolvimento Científico e Tecnológico (CNPq, Brazil) for funding the project through the Universal Call.

\section{Literature Cited}

Aragão, C. A.; Santos, J. S.; Queiroz, S. O. P.; Dantas, F. Avaliação de cultivares de melão sob condições de estresse salino. Revista Caatinga, v.22, p.161-169, 2009.

Bione, M. A. A.; Paz, V. P. da S.; Silva, F. da; Ribas, R. F.; Soares, T. M. Crescimento e produção de manjericão em sistema hidropônico NFT sob salinidade. Revista Brasileira de Engenharia Agrícola e Ambiental, v.18, p.1228-1234, 2014. http://dx.doi. org/10.1590/1807-1929/agriambi.v18n12p1228-1234

Ferreira, D. F. Sisvar: A computer statistical analysis system. Ciência e Agrotecnologia, v.35, p.1039-1042, 2011. http://dx.doi. org/10.1590/S1413-70542011000600001

Furlani, P. R. Hydroponic vegetable production in Brazil. Acta Horticulturae, v.2, p.777-778, 1999. http:// dx.doi.org/10.17660/ ActaHortic.1999.481.98

Hasanuzzaman, M.; Alam, M. M.; Rahman, A.; Hasanuzzaman, M.; Nahar, K.; Fujita, M. Exogenous proline and glycine betaine mediated upregulation of antioxidant defense and glyoxalase systems provides better protection against salt-induced oxidative stress in two rice (Oryza sativa L.) varieties. BioMed Research International, v.2014, p.1-17, 2014. https://doi. org/10.1155/2014/757219

Lira, R. M. de; Silva, Ê. F. de F. e; Silva, G. F. da; Santos, A. N. dos; Rolim, M. M. Production, water consumption and nutrient content of Chinese cabbage grown hydroponically in saline water. Revista Ciência Agronômica, v.46, p.497-505, 2015.

Luengo, R. de F. A.; Calbo, A. G. Embalagens para comercialização de hortaliças e frutas no Brasil. 1.ed. Brasília: Embrapa Hortaliças, 2009. 256p.
Maciel, M. P.; Soares, T. M.; Gheyi, H. R.; Rezende, E. P. L.; Oliveira, G. X. S. Produção de girassol ornamental com uso de águas salobras em sistema hidropônico NFT. Revista Brasileira de Engenharia Agrícola e Ambiental, v.16, p.165-172, 2012. http:// dx.doi.org/10.1590/S1415-43662012000200006

Magalhães, A. C. N. Análise quantitativa do crescimento. In: Ferri, M. G. (ed.). Fisiologia vegetal. São Paulo: Editora da Universidade de São Paulo, 1985. Cap.8, p.332-349.

Mantovani, E. C.; Delazari, F. T.; Dias, L. E.; Assis, I. R. de; Vieira, G. H. S.; Landim, F. M. Eficiência no uso da água de duas cultivares de batata-doce em resposta a diferentes lâminas de irrigação. Horticultura Brasileira, v.31, p.602-606, 2013. http://dx.doi. org/10.1590/S0102-05362013000400015.

Navarro, J. M.; Garrido, C.; Martinez, V.; Carvajal, M. Water relations and xylem transport of nutrients in pepper plants grown under two different salts stress regimes. Plant Growth Regulation, v.41, p.237245, 2003. https://doi.org/10.1023/B:GROW.0000007515.72795.c5

Paulus, D.; Dourado Neto, D.; Frizzone, J. A.; Soares, T. M. Produção e indicadores fisiológicos de alface sob hidroponia com água salina. Horticultura Brasileira, v.28, p.29-35, 2010. http://dx.doi. org/10.1590/S0102-05362010000100006.

Paulus, D.; Paulus, E.; Nava, G. A.; Moura, C. A. Growth, water consumption and mineral composition of lettuce in hydroponic system with saline water. Revista Ceres, v.59, p.110-117, 2012. http://dx.doi.org/10.1590/S0034-737X2012000100016

Richards, L. A. Diagnosis and improvement of saline and alkali soils. Washington: U.S. Department of Agriculture. 1954. 160p. Agricultural handbook, 60

Santos Júnior, J. A.; Gheyi, H. R.; Cavalcante, A. R.; Dias, N. da S.; Medeiros, S. de S. Produção e pós-colheita de flores de girassóis sob estresse salino em hidroponia de baixo custo. Engenharia Agrícola, v.36, p.420-432, 2016. http://dx.doi.org/10.1590/18094430-Eng.Agric.v36n3p 420-432/2016

Santos Júnior, J. A.; Gheyi, H. R.; Cavalcante, A. R.; Medeiros, S. de S.; Dias, N. da S.; Santos, D. B. dos. Water use efficiency of coriander produced in a low-cost hydroponic system. Revista Brasileira de Engenharia Agrícola e Ambiental, v.19, p.1152-1158, 2015. http:// dx.doi.org/10.1590/1807-1929/agriambi.v19n12p1152-1158.

Silva, A. O. da; Soares, T. M.; Silva, Ê. F. de F. e; Santos, A. N. dos; Klar, A. E. Consumo hídrico da rúcula em cultivo hidropônico NFT utilizando rejeitos de dessalinizador em Ibimirim-PE. Irriga, v.17, p.114-125, 2012. http://dx.doi.org/10.15809/irriga.2012v17n1p114

Silva, F. V. da; Duarte, S. N.; Lima, C. J. G. de S.; Dias, N. da S.; Santos, R. S. da S.; Medeiros, P. R. F. Cultivo hidropônico de rúcula utilizando solução nutritiva salina. Revista Brasileira de Ciências Agrárias, v.8, p.476-482, 2013. http://dx.doi.org/10.5039/agraria.v8i3a1689.

Silva, J. V.; Lacerda, C. F. de; Costa, P. H. A. da; Enéas Filho, J.; Gomes Filho, E.; Prisco, J. T. Physiological responses of $\mathrm{NaCl}$ stressed cowpea plants grown in nutrient solution supplemented with $\mathrm{CaCl}_{2}$. Brazilian Journal of Plant Physiology, v.15, p.99-105, 2003. http://dx.doi.org/10.1590/S1677-04202003000200005.

Silva, M. G. da; Soares, T. M.; Gheyi, H. R.; Oliveira, I. de. S.; Silva Filho, J. A. da; Carmo, F. F. do. Frequency of recirculation of nutrient solution in hydroponic cultivation of coriander with brackish water. Revista Brasileira de Engenharia Agrícola e Ambiental, v.20, p.447-454, 2016. http://dx.doi.org/10.1590/1807-1929/agriambi.v20n5p447-454.

Silva, P. F. da; Cavalcante, V. S.; Santos, J. C. C. dos; Costa, E. S.; Barbosa, J. T. V. Análise quantitativa da cebolinha irrigada com água salina. Comunicata Scientiae, v.5, p.241-251, 2014. 
Soares, H. R.; Silva, Ê. F. de F. e; Silva, G. F. da; Pedrosa, E. M. R.; Rolim, M. M.; Santos, A. N. Lettuce growth and water consumption in NFT hydroponic system using saline water. Revista Brasileira de Engenharia Agrícola e Ambiental, v.19, p.636-642, 2015. http:// dx.doi.org/10.1590/1807-1929/agriambi.v19n7p636-642.

Soares, T. M.; Duarte, S. N.; Silva, Ê. F. de F. e; Paz, V. P. da S.; Oliveira, J. L. B. Uso de águas salobras em sistemas hidropônicos de cultivo. In: Gheyi, H. R.; Dias, N. da S.; Lacerda, C. F. de; Gomes Filho, E. (eds.). Manejo da salinidade na agricultura: Estudos básicos e aplicados. Fortaleza: INCTSal, 2016. Cap.23, p.373-394.
Tabagiba, S. D.; Moraes, G. A. B. K.; Nascimento, K. J. T.; Peloso, A. F. Limitações fotossintéticas em folhas de plantas de tomateiro submetidas a crescentes concentrações salinas. Engenharia na Agricultura, v.22, p.138-149, 2014.

Taiz, L.; Zeiger, E. Plant physiology. 5.ed. Sunderland: Sinauer Associates Inc., 2009. 782p.

Willadino, L.; Camara, T. R. Tolerância das plantas à salinidade: Aspectos fisiológicos e bioquímicos. Enciclopédia Biosfera, v.6, p.1-23, 2010. 